\title{
3
}

\section{From New Public Management to New Public Governance: The implications for a 'new public service'}

\author{
Helen Dickinson
}

\section{Introduction}

Rarely a day goes by without the performance of government and public services providing a topic of discussion and debate within the media. Whether this is in relation to child protection services, the quality of built infrastructure, the operation of border controls or rising healthcare costs, what is clear is that there is extensive public scrutiny of governments and the services they deliver and to a degree we have not previously seen. This greater focus on the activities of governments takes place against a background of transition. The reasons for this have been well rehearsed and relate to factors such as shifting demographic structures and disease burden, rising citizen expectations, rapid advances in technology and a host of other related challenges, all of which mean that governments are under pressure to be more efficient and effective. Reform has become a common refrain within many governments around the world in their search for new ways in which to deliver services that are less expensive and more appropriate to the wants and needs of individuals and communities. 
Within this context, the reform of governance has received significant attention. Governance can, and has been, defined in any number of ways (for example, Kjaer 2004; Pierre and Peters 2000). For the purposes of this chapter, governance can be understood as the coordination of institutions and agency in a given policy area towards collective objectives. It therefore describes the division of control and patterns of interaction among key (types of) actors in that policy area. Over the past 30 years it has been argued that governance reform has been a necessary action - first, in response to the perceived failings of 'big government' and, subsequently, in response to the unanticipated consequences of the market mechanisms that were intended corrections to unwieldy government arrangements. In more recent years, the concept of new public governance (NPG) has come to the fore to describe the plural nature of the contemporary state, where multiple different actors contribute to the delivery of public services and the policymaking system. This chapter explores the purported shifts in governance forms and the degree to which these have resulted in significant changes to the practice of public services. Rhetorically speaking, it would seem that governments have gone through a period of profound governance reform; however, in practice, the impacts of this reform process are less palpable. The reality is that hybrid forms of governance prevail, with a complex overlay of different governance arrangements. This observation has significant implications for the way we organise public services and the kinds of skills and values we require of public servants. The chapter considers these implications in terms of how we might research hybrid forms, and sets out three lessons concerning the management of these arrangements in practice.

\section{The rise of new public governance}

The period from the late 1940s until the 1970s is often characterised in governance terms as being a time of hierarchy and the era of public administration (Peck and Dickinson 2008). Over time this mode was critiqued for being inefficient, consuming too much of a nation's resources and serving the interests of public service professionals rather than those of citizens. It was often perceived that tight-knit networks dominated the centre of governments, and that these were difficult to penetrate and served only the interests of a few (Dickinson 2014b). The solution to these challenges in many liberal economies was to make governments more 'businesslike' by the introduction 
of markets into some areas of the public sector and, in the process, 'hollowing out' government (Peters 1993). In many countries the paradigm of new public management was felt strongly as governments sought to shift governance forms away from hierarchies and towards markets (Ferlie et al. 1996). As public services started to be delivered, not just by the public sector, but also by commercial and community organisations on the basis of contracts, government started to become more fragmented. The process also resulted in the reduction of the discretion and influence of public service professionals, in turn also 'hollowing out' their role (Skelcher 2000).

Fragmentation emerged from the turn to the market, meaning that a range of organisations needed to cooperate with one another to deliver public services. In effect, the marketisation process essentially served to multiply the networks it was intended to replace. As Bevir and Rhodes (2011: 205) explain:

Fragmentation created new networks but also ... increased the membership of existing networks, incorporating both the private and [the] voluntary sectors ... government swapped direct for indirect control, so that central departments are no longer either necessarily or invariably the fulcrum of a network. The government can set the limits to network actions: after all, it still funds the services. But it has also increased its dependence on multifarious networks.

A primary implication of the introduction of market forms was that there were now ever more complex processes of interactions between a range of different partners and these often had a great deal of autonomy from the state. This gave rise to a new form of governance but one 'without government' (Rhodes 1996). As Rhodes (1997: 15) explains, governance became understood as 'self-organizing [sic], inter-organisational networks' that are typically interdependent while enjoying significant autonomy from the state. Networks started to receive attention as they were viewed as a way to 'overcome the limitations of anarchic market exchange and top-down planning in an increasingly complex and global world' (Jessop 2003: 101-02). This latest shift towards networked forms of governance is largely equated with the move towards what Osborne (2006) refers to as new public governance, which has a strong focus on collaboration and horizontal ties between individuals and agencies. Table 3.1 sets out an overview of Osborne's three-stage model, characterising public administration, new public management and new public governance. 
THE THREE SECTOR SOLUTION

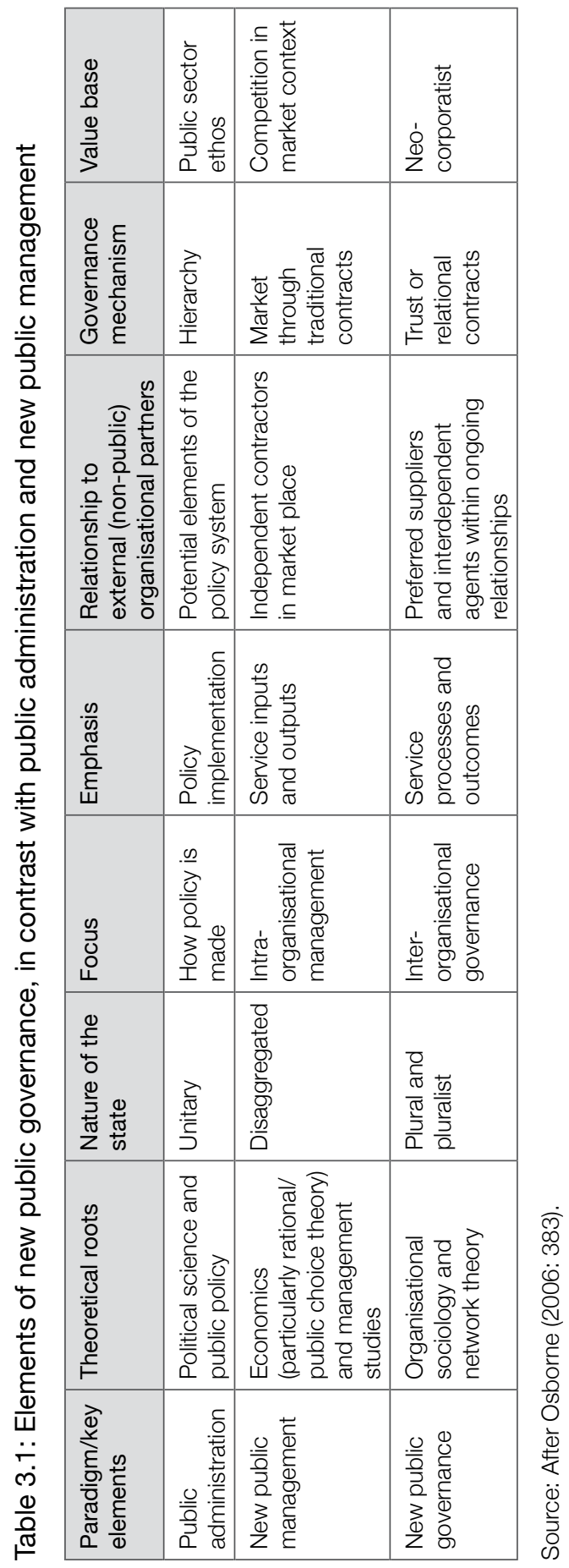


The account set out here is necessarily brief and has been rehearsed in a number of other settings in much detail (for example, Dickinson 2014b). To summarise the key points, the academic literature suggests what we have seen is the transformation of the state in terms of the ways in which it governs society, away from a strongly centralised executive and a controlling unified state to a fragmented and decentralised entity (Rhodes 2007).

The predominant focus is on the increasing significance of governance through networks as an alternative to markets and hierarchy ... The state, it is argued, can no longer assume a monopoly of expertise or resources necessary to govern, and must look to a plurality or interdependent institutions drawn from the public, private and voluntary sectors. (Newman 2004: 71)

In the next section, we examine the degree to which the shift from hierarchical through market to network forms of governance has been realised in practice.

\section{A new public service?}

Whether these shifts in governance forms have created a new public service is difficult to answer given that public services are continually evolving and, as Brunsson (2009) reminds us, reform is not necessarily always driven by the goal of making specific changes, but may instead be largely symbolic in nature:

[R]eform can be regarded as part of organizational stability rather than of organizational change. Reforms are often presented as dramatic oneoff changes, and they may sometimes lead to changes. But reform in itself is more often a standard repetitive activity. Reforms are routines rather than breaks in organizational life. (Brunsson 2009: 44)

Having noted this, indications seem to suggest we have not seen an expansive shift in governance forms or indeed the creation of 'new' public services (Bell and Hindmoor 2009). While there has been extensive rhetoric concerning governance shifts, the reality is that rather than seeing wholesale shifts we are faced instead with overlapping layers of different reform processes. Rather than there being a clear dominant mode of governance, we are faced with hybrid arrangements (Crouch 2005). As Brandsen et al. (2005: 750) explain, 'empirically speaking, it appears far easier to find arrangements that are hybrid or "fuzzy arrangements". 
Jessop (2004: 66) explains that 'whilst the state may have become less hierarchical and less centralised, that trend does not necessarily exclude a continuing and central political role for nation states'. Indeed, some commentators suggest these changes could, in fact, increase the state's control over society. As Marinetto (2003: 606) argues, 'these characteristics of modern government should not be equated with the permanent paralysis of the state. Although government has been subject to restructuring, these reforms have tended to reinforce the ability of the central core to exert control.' Indeed, with fewer 'hard' levers of power, 'softer' policy instruments have become more appropriate (Pierre and Peters 2000). These are more indirect instruments of control, but arguably they are just as effective in contemporary society (see, for example, debates over notions of the role of governments in 'nudging' citizens into action: Thaler and Sunstein 2008). Although governments may no longer be directly in charge of individuals and departments, as they would be in a hierarchical arrangement, governments may still set 'the rules of the game' so that all interactions take place in the 'shadow of hierarchy' (Scharpf 1997; Jessop 2000, 2003). The state may also maintain a steering role through the use of its considerable resources (Skelcher 2000; Holliday 2000).

The analogy of a palimpsest is helpful in understanding the impact of successive governance reform processes. Originating in ancient Roman times, a palimpsest is a page that has text scraped or washed off so that it can be used for another document. In employing such an approach, the majority of text might be removed, but it is often possible to still view aspects of the previous content. Within the discipline of geography, this analogy has been used to understand landscapes. In a region where the landforms that make up the landscape are not of the same age, each successive episode of landscape change is considered to be a different 'layer', which is laid like a blanket across the surface of the landscape (Bailey 2007). This analogy is used to show that successive landscape-changing episodes may have different manifestations in time and space and can also create unequal signatures - that is, some landscapes are very sensitive to external forces, while others have changed very little over significant periods. If we extend this analogy to governance reform and public services, we find similar patterns. In some policy areas the reforms associated with public administration have stuck more firmly, while others have 
been more significantly impacted by NPM or NPG-type reforms. The result of this are governance landscapes that bear the markers of these successive reform efforts, presenting as different forms of hybrid arrangements that involve 'combinations of modes of governance that are temporally and contextually unique' (Skelcher et al. 2013: 2).

This section has sought to demonstrate that the reform of governance is rarely as simple or straightforward as is suggested and that layers of previous governance regimes often endure, interacting in a range of different ways. Miller et al. (2008: 944) write that 'despite the comforting demarcation of domains accomplished by words such as economy, society, technology and politics, "impurity" is the rule and hybrids are the norm'. Crouch (2005) concurs, arguing that hybrids are no longer the exception, but the norm, in advanced capitalist economies. Yet conceptually most scholars remain wedded to ideal governance forms (van der Heijden 2015), and in practice public service delivery debates fixate on long-held dualisms such as public/ private, market/hierarchy and consumer/bureaucrat. This can be problematic for those acting in a hybrid world, and the next section seeks to explore ways to navigate complex contexts.

\section{Operating in a hybrid world}

To date research has not considered the unique challenges that hybridity creates in a comprehensive way, nor the demands it places on the skills and capabilities of managers and leaders (van der Heijden 2015). While there is an extensive literature that examines the skills and capabilities needed for collaboration (Sullivan et al. 2011) and boundary spanning (Williams 2012) and the various competencies needed for different forms of relationships with service providers (Alford and O'Flynn 2012), there is no coherent theoretical model that brings these together, nor guidance on what this means for the management of complex service delivery systems in practice. This section considers first how we might better understand hybrid forms through a model of decentred governance and then sets out three areas that are helpful to consider in thinking about navigating hybridity: changing relationships; value and values; and workforce capacities and capabilities. 


\section{Decentred governance}

In the governance literature, Bevir and Rhodes (for example, 2003, $2006,2011)$ have argued that what is needed is a decentred account of the state. They concur with the view that governance processes are not clear-cut, are more complex than the mainstream literature would suggest and, 'if governance is constructed differently, contingently and continuously, we cannot have a tool kit for managing it' (Rhodes 2007: 1257). They argue that, to date, governance theories have attempted to identify essential properties and then imply that these must be general and characteristic of all cases of governance. Yet such a perspective makes sense only if we consider that government has some sort of essence that exists in a real, ontological sense. A decentred position moves away from this perspective, arguing that essentialist structures are not what is important, but rather the understandings and meanings that individuals attach to actions, practices and institutions (Rhodes 2007).

Practically, what these arguments mean for the everyday operation of public services is that we need to move from thinking about reform and change being driven primarily through structural factors and focus more on the personal agency of actors. As Newman (2001: 20) explains, 'theories of governance that focus on self-steering capacities of networks and partnerships tend to marginalise issues of agency and individual, institutional and state power'. Within the decentred account of governance, agency and micro-institutional factors are viewed with far more importance than simply macro-level structures. As such, we cannot treat individuals as unitary subjects or culture as undifferentiated. A decentred analysis instead:

Places agency and meaning at the heart of network governance. It focuses on the diverse practices of governance, practices that are themselves composed of multiple individuals acting on changing webs of beliefs rooted in overlapping traditions. Patterns of governance arise as the contingent products of diverse actions and political struggles informed by the beliefs of agents as they arise in the context of traditions. This approach focuses on beliefs and ideas, on the games people play, and on the role of both in explaining how the practices of network governance change. (Rhodes 2007: 1252) 
While a decentred approach acknowledges there have been changes in terms of the dominant modes of governance, it does not characterise this as a unilateral change that has been experienced in the same way by all people. Patterns of rule are understood to emerge from a range of diverse actions and political struggles. Agents confront dilemmas that are brought about in the course of everyday life when beliefs are encountered that contrast with their own. These dilemmas push people into reconsidering their own beliefs, which gives rise to rival positions and the reformation of governance.

A decentred approach focuses on the importance of narratives and stories, rather than simply macro-structures of governance (Bevir and Rhodes 2006). Rhodes (2007) goes as far as to suggest that we should give up the search for management techniques and strategies for practice and instead tell and listen to stories: 'a decentred approach focuses on the social construction of patterns of rule through the ability of individuals to create meanings in action' (Bevir and Rhodes 2011: 209). Such a change involves moving attention away from institutions, structures and social logics and replacing 'aggregate concepts that refer to objectified social laws with narratives that explain actions by relating them to the beliefs and desires that produce them' (Bevir and Rhodes 2011: 210). The focus of research therefore moves away from the state and instead focuses on 'a diverse range of agencies, apparatuses and practices producing varied mechanisms of control and varied forms of knowledge that make areas or aspects of social life available for governmental action' (Finlayson and Martin 2006: 167).

\section{Changing relationships}

The above discussion offers some sense of how we might go about researching governance forms, but offers little for individuals and organisations managing complex hybrid governance forms in practice. A first lesson to consider in managing hybrid governance arrangements is that the days of certainty and stability are long gone. What singular macro-governance structures give are a sense of stability and the rules of the game at any one time. Operating in a hybrid context means there may be multiple and conflicting systems interacting with one another at any time. Before reflecting on this further, it is important to acknowledge that uncertainty is not a new thing and it is highly unlikely there was ever such a thing as a time of certainty for all. 
There is often a tendency to romanticise the past and remember aspects of context that were never really true of particular periods and then to bemoan the loss of particular aspects that never were. Relationships between individuals and/or groups are rarely static and the kinds of mechanisms that are used to govern these links will invariably change over time. What may be the issue in this case is the magnitude of changes to relationships.

At present there is significant debate concerning the relationship between the state, civil society and community organisations. Community organisations are facing increased pressure to demonstrate their value as governments move away from grant-based systems of funding towards contracting for particular services. This is not a new phenomenon by any degree, but arguably has become more pressing in recent months with the rise of the commissioning agenda (Dickinson 2014c) and initiatives such as the National Disability Insurance Scheme (Dickinson et al. 2015). Some in the community sector have argued that these changes are fundamentally detrimental to the nature and existence of the sector. As an example of this, in a speech, the Chief Executive of the Brotherhood of St Laurence, Tony Nicholson (2014), argued that 'in the next year or two decisions will be made about' the community welfare sector 'that in all likelihood will be irrevocable. I fear if the wrong decisions are taken, they will inevitably lead to the erosion of what our voluntary organisations have stood for [for] over a century.' The idea that we can know what might constitute 'right' and 'wrong' decisions in this context is a difficult one given that the community sector has always comprised a range of different individuals, groups, interests, values and world views, making it difficult for the sector to hold one consistent and comprehensive perspective on any range of issues (Alcock 2010).

The idea that the relationship between the community sector and the state has been static for the previous 30 years seems to be at odds with the lived experience of most. As Rob Macmillan (2013) argues, the relationship between different actors and agencies is always in flux and is highly contingent on the kinds of changes and events taking place in broader society. Relationships are not fixed, but are constantly in a process of negotiation and renegotiation at a micro level, with structural and macro-governance forces explaining only some of the shifts in the parameters of these relationships. At some times this change is more noticeable than the general day-to-day change, 
and Macmillan refers to these times as a period of great unsettlement, when there is a more rapid wholesale change across a sector. The analogy of an earthquake is helpful in thinking about this. The Earth's shell is divided into a number of tectonic plates that glide over the mantel (the rocky inner layer just above the core). Most of the time, these plates move past one another without us noticing, but the stress that builds up over time eventually leads to an earthquake, which can unleash significant damage. Similarly, the boundaries between the various sectors are often in flux, but we may not always recognise this until there is a significant shift. Those on the boundaries may feel this more intensely than those who are further away from the epicentre and will often live with foreshocks or aftershocks from this boundary shift.

Building on the earthquake analogy, we might suggest that relationships between government and the community sector in Victoria are either in the wake of this sort of earthquake event or just on the cusp. Similar sorts of debates and tensions are also taking place in other jurisdictions, and these periods of great upheaval have also existed historically (Macmillan and Buckingham 2013). No doubt this is a difficult time for many in the community welfare sector, but not all community organisations will react in the same way to these changes, and nor should they. This is a diverse sector and we should celebrate this, even if this does make it somewhat difficult to 'steer' at times. In times of change there are always opportunities for agency, no matter how small. Earthquakes, of course, are rarely good things for those in affected areas in the short term, although some positives have been drawn from recent experiences in New Zealand and also Haiti. It is often a time of rebuilding, and community cohesion emerges in overcoming adversity. Where earthquakes are minor, it can remind people of the importance of making sure that structures are able to withstand possible further shocks. Just because there has been an earthquake it does not mean the tectonic plates stop moving, and the relationship between sectors will always be in a process of negotiation in a similar way. We should not take stability for granted and should therefore always be prepared for potential change. 


\section{Value and values}

If we do not have consistency in terms of governance and relationships between sectors, the issue of value and values becomes incredibly important in navigating hybridity. Value typically refers to the worth or the impact of a particular activity or initiative (Dickinson 2008). Values refer to the subjectively held norms or principles of individuals or groups (Bozeman 2007).

Many argue that community sector organisations are values based and this influences how they conduct activities and make decisions (Westall 2009). Being clear about the kinds of values that underpin different sorts of activities and the ways different groups add value to processes may help us navigate hybridity in practice. Of course, this is easy to say and sometimes more challenging to do, and the current focus on commissioning and associated contracting processes is forcing community organisations to think about the value they produce and to be mindful of straying too far from their initial values. In practice, values and value creation may be connected. When we focus on the types of value produced, we need to be cognisant that, if values are part of that creation process, the ways in which community sector organisations and government interact do not undermine this. For example, it has been argued that delivering services under contract with government has led to 'mission drift', where organisations have moved away from activity that has previously been their core concern (Greer and Horst 2014), thus presenting a challenge to their values. Where community organisations can be clear about their values and strengths, they are able to challenge issues that are not appropriate and advocate on behalf of their communities. Community organisations need not be 'policy victims', but for this to be achieved there needs to be constructive dialogue on all sides and not just finger pointing (Dickinson 2014a).

There are various forms of value that are created by the community sector, but comparing forms of value is challenging as we often lack the metrics or techniques for comparison. Deciding the most important forms on which to focus requires negotiation and discussion to reach some form of resolution (Trainor 2006). It is important to note that specific forms of value are not an innate trait of a particular organisational form or sector. While there is lots of attention given to the notion that community sector organisations create particular forms 
of value, or that they hold unique sets of value, this is not necessarily the case. This means that neither specific organisational forms nor specific sectors hold a natural advantage in creating specific forms of value. Recent research from social care services in the United Kingdom suggests that rather than the sector within which an organisation resides being the most important factor in driving performance, the size of the organisation makes an important contribution, with microproviders offering the potential to provide more personalised support than larger providers (Needham et al. 2015).

While formal governance processes are clearly important in terms of influencing the ways in which organisations behave, they also signal to individuals and groups what is to be valued within that setting. It has been shown repeatedly that organisations respond to stimuli in their environment and that, in commissioning processes and service design processes, government must be cognisant of how incentives influence action. It cannot be assumed that community sector organisations will always create particular forms of value; the environment within which they operate matters and shapes roles, behaviour and characteristics. For example, if more market-based models are used, and incentives geared towards satisfying self-interest are embedded, it is no surprise that community sector organisations may begin to behave more like what we would expect from private sector organisations (Alford and O'Flynn 2012). It is also the case that the lines of demarcation between government, business and the community sector are blurring under a new order 'where the private sector practises social responsibility and states seek to be more entrepreneurial, while community organisations become more and more business-like' (Smyth 2014: 2). What this means for commissioning processes is being explicit about the particular sorts of value we seek to reach the desired community outcomes. It is also critical for government to be clear about the forms of value it seeks when undertaking service delivery design processes, to ensure it does not create incentives that will focus providers away from the value that is needed to produce outcomes.

\section{Workforce competency and capacity}

The final lesson in navigating hybridity relates to the competencies and capacities of workforces. In terms of the skill sets and capabilities of public servants, Alford and O'Flynn (2012) argue that the effective 
management of different relational forms draws on sets of competencies that are very different to those that are traditionally thought to be central to public services. This was clearly illustrated in recent research by Dickinson and Sullivan (2014), drawing on research into Australian public services, but is also reflected in the broader literature (Needham et al. 2014) and UK-based research (Needham and Mangan 2014). These various investigations suggest that public services typically recruit for quite traditional sets of skills and capabilities - often related to professional roles. Yet, in navigating complex hybrid systems, there is a series of 'softer' and more relational skills required of the workforce, such as the ability to communicate narratives effectively, collaborate, critically analyse multiple forms of evidence, coproduction skills and international literacies. While elements of these are present in the existing system, this is often despite recruitment and development processes, rather than because of them.

What this means in practice is that public and community organisations alike need to pay close attention to the skills and capabilities of their workforce in a strategic sense. Typically, workforces have been built up over time by recruiting to particular programs and services without thinking about the workforce's capacity and capability in a broader way. A number of different commentators have argued for a return to more traditional values of government, albeit with a new emphasis.

Geoff Mulgan (2012: 21) speaks of the relational state, which 'connects back to the longstanding concern of governments of all kinds to retain and grow public trust. But in other respects it is new, a product of specific 21 st-century circumstances that are forcing governments to attend much more systematically to the quality of their relationships with citizens.' Rod Rhodes (2014) similarly argues for the importance of human facets of managing and that public administrators need to rediscover the 'craft' of this endeavour. Most commentators agree that now and in the future it will not be sufficient for governments and third-party providers of government services to focus on measures of efficiency and effectiveness, and careful consideration will need to be given to the relational aspects of service delivery (Dickinson 2014b). Moreover, evidence from the United Kingdom suggests that successful commissioning lies not simply in contracting abilities, but also in market stewardship (Livingstone and Macmillan 2015), working collaboratively with providers (Miller and Rees 2014) and developing legitimacy in the eyes of a range of different constituencies (Dickinson 
et al. 2010). Taken together, these tasks suggest that we may need to think about recruitment, management and development of workforces in both public and private sectors in rather different ways if we are to enable individuals to develop and use these kinds of skills.

\section{Conclusions}

The academic literature on the reform of governance offers a compelling narrative of government and public services, suggesting that traditional hierarchical arrangements have, over time, been replaced with more effective and efficient mechanisms of governance. The rather simplistic argument suggests that market forces were introduced to overcome the inherent limitations of hierarchies. When the inevitable limitations of markets eventuated, a discourse of networks and NPG emerged ostensibly to counter these challenges. This chapter has explored the experience of this transition in governance arrangements to examine whether the reality of this transition has kept pace with the rhetoric. It finds that the transition between governance arrangements is rarely as clear-cut and straightforward as the academic literature typically presents it to be. Rather than a wholesale shift to new governance regimes, what happens in practice is that a rather more complex picture emerges of hybrid arrangements comprising features of different forms of governance systems at the same time. Yet, despite hybridity being a relatively well-established concept in the literature, we still lack effective theorisation of this and detail concerning how to navigate the complexities that this produces or the implications for the kinds of skills and abilities that public servants require to operate within this context. There are, however, lessons that we might take from the literature such as moving away from certainties, understanding the importance of values and paying close attention to the skills and capabilities of the workforce. While there are no easy answers when it comes to issues of managing hybridity, paying attention to these factors ultimately affords greater agency and a sense of humanity to the delivery of public services. 


\section{References}

Alcock, P. 2010. Partnership and mainstreaming: Voluntary action under New Labour. Working Paper 32. Third Sector Research Centre, Birmingham, UK.

Alford, J. and J. O'Flynn. 2012. Rethinking Public Services: Managing with external providers. Basingstoke, UK: Palgrave Macmillan.

Bailey, G. 2007. 'Time perspectives, palimpsests and the archaeology of time.' Journal of Anthropological Archaeology 26: 198-223.

Bell, S. and A. Hindmoor. 2009. Rethinking Governance: The centrality of the state in modern society. Cambridge: Cambridge University Press.

Bevir, M. and R. A. W. Rhodes. 2003. Interpreting British Governance. London: Routledge.

Bevir, M. and R. A. W. Rhodes. 2006. Governance Stories. London: Routledge.

Bevir, M. and R. A. W. Rhodes. 2011. 'The stateless state.' In The SAGE Handbook of Governance, ed. M. Bevir, 203-17. London: Sage.

Bozeman, B. 2007. Public Values and Public Interest: Counterbalancing economic individualism. Washington, DC: Georgetown University Press.

Brandsen, T., W. van de Donk and K. Putters. 2005. 'Griffins or chameleons? Hybridity as a permanent and inevitable characteristic of the third sector.' International Journal of Public Administration 28: 749-65.

Brunsson, N. 2009. Reform as Routine: Organizational change and stability in the modern world. Oxford: Oxford University Press.

Crouch, C. 2005. Capitalist Diversity and Change: Recombinant governance and institutional entrepreneurs. Oxford: Oxford University Press.

Dickinson, H. 2008. Evaluating Outcomes in Health and Social Care. Bristol: Policy Press. 
Dickinson, H. 2014a. Blog. powertopersuade.org.au.

Dickinson, H. 2014b. Performing Governance: Partnerships, culture and New Labour. Basingstoke, UK: Palgrave Macmillan.

Dickinson, H. 2014c. 'Public service commissioning: What can be learned from the UK experience?' Australian Journal of Public Administration 73(1): 14.

Dickinson, H. and H. Sullivan. 2014. Imagining the 21st Century Public Service Workforce. Melbourne: School of Government, University of Melbourne.

Dickinson, H., E. Peck, J. Durose and E. Wade. 2010. 'The role of cultural performance in health care commissioning.' In Culture and Climate in Health Care Organizations, eds J. Braithwaite, P. Hyde and C. Pope, 196-207. Basingstoke, UK: Palgrave Macmillan.

Dickinson, H., H. Sullivan and C. Needham. 2015. 'Self-directed care funding: What are the implications for accountability?' Australian Journal of Public Administration 73(4): 417-25.

Ferlie, E., L. Ashburner, L. Fitzgerald and A. Pettrigrew. 1996. The New Public Management in Action. Oxford: Oxford University Press.

Finlayson, A. and J. Martin. 2006. 'Post-structuralism.' In The State: Theory and issues, eds C. Hay, M. Lister and D. Marsh, 155-71. Basingstoke, UK: Palgrave Macmillan.

Greer, P. and C. Horst. 2014. Mission Drift: The unspoken crisis facing leaders, charities and churches. Ada, Mich.: Bethany House Publishers.

Holliday, I. 2000. 'Is the British state hollowing out?' Political Quarterly 71: 167-76.

Jessop, B. 2000. 'Governance failure.' In The New Politics of British Local Governance, ed. G. Stoker, 11-32. Basingstoke, UK: Macmillan.

Jessop, B. 2003. 'Governance and meta-governance: On reflexivity, requisite variety and requisite irony.' In Governance as Social and Political Communication, ed. H. Bang, 101-16. Manchester: Manchester University Press. 
Jessop, B. 2004. 'Multi-level governance and multi-level metagovernance: Changes in the European Union as integral moments in transformation and reorientation of contemporary statehood.' In Multi-Level Governance, eds I. Bache and M. Flinders, 49-74. Oxford: Oxford University Press.

Kjaer, A. M. 2004. Governance. Cambridge: Polity Press.

Livingstone, I. and R. Macmillan. 2015. 'More than a provider: The voluntary sector, commissioning and stewardship for a diverse market in criminal justice.' Voluntary Sector Review 6(2): 221-30.

Macmillan, R. 2013. 'De-coupling the state and the third sector? The "big society" as a spontaneous order.' Voluntary Sector Review 4(2): 185-203.

Macmillan, R. and H. Buckingham. 2013. 'A strategic lead for the third sector? Some may lead, but not all will ever follow.' In Third sector futures dialogues. Big Picture Paper 5. Third Sector Research Centre, Birmingham, UK.

Marinetto, M. 2003. 'Governing beyond the centre: A critique of the Anglo-governance school.' Political Studies 51(3): 592-608.

Miller, P., L. Kurunmäki and T. O'Leary. 2008. 'Accounting, hybrids and the management of risk.' Accounting, Organizations and Society 33: $942-67$.

Miller, R. and J. Rees. 2014. 'Mental health commissioning: Master or subject of change?' Mental Health Review 19(3): 145-55.

Mulgan, G. 2012. 'Government with the people: The outlines of a relational state.' In The Relational State, eds G. Cooke and R. Muir, 20-34. London: Institute for Public Policy Research.

Needham, C. and C. Mangan. 2014. The 21st Century Public Servant. Birmingham, UK: University of Birmingham.

Needham, C., K. Allen, K. Hall, S. McKay, J. Glasby, S. Carr, R. Littlechild and D. Tanner. 2015. Micro-enterprises: Small enough to care? Birmingham, UK: University of Birmingham. 
Needham, C., C. Mangan and H. Dickinson. 2014. The 21st Century Public Service Workforce: Eight lessons from the literature. Birmingham, UK: University of Birmingham.

Newman, J. 2001. Modernising Governance: New Labour, policy and society. London: Sage.

Newman, J. 2004. 'Modernizing the state: A new form of governance?' In Remaking Governance: Peoples, politics and the public sphere, ed. J. Newman, 119-38. Bristol: The Policy Press.

Nicholson, T. 2014. The future of the community welfare sector. Speech, 27 May 2014. Available from: library.bsl.org.au/jspui/ handle/1/5804 (accessed 18 August 2015).

Osborne, S. P. 2006. 'The new public governance?' Public Management Review 8(3): 377-87.

Peck, E. and H. Dickinson. 2008. Managing and Leading in Inter-Agency Settings. Bristol: Policy Press.

Peters, B. G. 1993. 'Managing the hollow state.' In Managing Public Organizations: Lessons from contemporary European experience, eds K. A. Eliassen and J. Kooiman. London: Sage.

Pierre, J. and B. G. Peters. 2000. Governance, Politics and the State. Basingstoke, UK: Macmillan.

Rhodes, R. A. W. 1996. 'The new governance: Governing without government.' Political Studies 44(4): 652-67.

Rhodes, R. A. W. 1997. Understanding Governance: Policy networks, governance, reflexivity and accountability. Buckingham, UK: Open University Press.

Rhodes, R. A. W. 2007. 'Understanding governance: Ten years on.' Organization Studies 28: 1243-64.

Rhodes, R. A. W. 2014. Recovering the 'craft' of public administration in network governance. Plenary Address to the International Political Science Association World Congress, Montreal, 19-24 July. Available from: raw-rhodes.co.uk/wp-content/uploads/2014/07/Rhodes-2014IPSA-Craft-Governance-final.pdf (accessed 22 August 2014). 
Scharpf, F. W. 1997. Games Real Actors Play. Actor-centred institutionalism in policy research. Boulder, Colo.: Westview Press.

Skelcher, C. 2000. 'Changing images of the state: Overloaded, hollowedout, congested.' Public Policy and Administration 15(3): 3-19.

Skelcher, C., H. Sullivan and S. Jeffares. 2013. Hybrid Governance in European Cities: Neighbourhood, migration and democracy. Basingstoke, UK: Palgrave Macmillan.

Smyth, P. 2014. The Lady Vanishes: Australia's disappearing voluntary sector. Seminar given at the Brotherhood of St Laurence, Melbourne, 14 August. Available from: library.bsl.org.au/jspui/ bitstream/1/6511/1/Smyth_The_lady_vanishes_Australias_ disappearing_voluntary_sector_paper_14Aug2014.pdf (accessed 6 October 2014).

Sullivan, H., P. Williams and S. Jeffares. 2011. 'Leadership for collaboration: Situated agency in practice.' Public Management Review 14(1): 41-66.

Thaler, R. H. and C. R. Sunstein. 2008. Nudge: Improving decisions about health, wealth and happiness. London: Yale University Press.

Trainor, S. F. 2006. 'Realms of value: Conflicting natural resource values and incommensurability.' Environmental Values 15(1): 3-29.

van der Heijden, J. 2015. 'Interacting state and non-state actors in hybrid settings of public service delivery.' Administration \& Society 47(2): 99-121.

Westall, A. 2009. Value and the third sector: Working paper on ideas for future research. Working Paper 25. Third Sector Research Centre, Birmingham, UK.

Williams, P. 2012. Collaboration in Public Policy and Practice: Perspectives on boundary spanners. Bristol: Policy Press. 
This text is taken from The Three Sector Solution: Delivering public policy in collaboration with not-for-profits and business, edited by John Butcher and David Gilchrist, published 2016 by ANU Press, The Australian National University, Canberra, Australia. 